the vocables in Melanesia for which we have discovered Polynesian affinities are found to carry that affinity back to Indonesia." $\mathrm{He}$ is "ready to pronounce the decree of Divorce upon Malay and Polynesian." Other judges of Indonesian will scarcely concur in this judgment.

It is impossible in the limits of this notice to give an adequate exposition of the value of Mr. Churchill's book to the student of Oceanic linguistics and ethnology. It is not only suggestive of points for discussion, but provides also material upon which the argument may be based. There is a bibliographical appendix, two maps, and a useful index. SIDNEY H. RAY.

\section{SCIENTIFIC PROGRESS IN THE UNIVERSITY OF OXFORD.}

THE annual report of the delegates of the University Museum, lately published, contains a very complete record of the scientific work done in the several depart. ments of the museum during the year 1910. In the department of physiology, special attention is directed to the establishment of an advanced practical course in physiological optics, under the direction of Prof. Gotch and Dr. Burch. A considerable amount of the requisite apparatus was made in the laboratory workshop. Prof. Arthur Thomson (human anatomy) announces that instruction in physical anthropology has now been systematically organised. The report of the Linacre professor of comparative anatomy (Prof. Bourne) also shows much evidence of steady progress. The list of additions to the collection is a long one, and numerous important memoirs have been published by members of the department during the past year.

Prof. Poulton submits a lengthy and interesting account of the work done in the rooms assigned to the Hope professor of zoology. A very fine collection and library of Oriental and British entomology, chiefly Hymenoptera, was presented by Mr. G. A. James Rothney; and other important accessions were received from numerous donors, among whom were $\mathrm{Mr}$. Herbert Druce, Commander J. J. Walker, Mr. J. H. Watson, Mr. S. A. Neave, Mr. W. A. Lamborn, and the Hon. Walter Rothschild. Special attention is directed to bred specimens received from Mr. A. D. Millar, of Durban, which prove that the conclusion tentatively arrived at by Mr. G. A. K. Marshall in 1902, that Euralia mima and $E$. wahlbergi are dimorphic forms of the same species, is in accordance with the fact. The collection of British Rhynchota, Hemiptera, and Homoptera belonging to the late Edward Saunders, and presented by the professor and Dr. G. B. Longstaff, is described as one of the most important additions ever made to the British collection in the department. Among the original memoirs published by workers in the department are Mr. H. Eltringham's important monograph on African mimetic butterflies and Mr. R. Shelford's contributions to the Genera Insectorum.

Noteworthy additions have been made to the anthropological collections contained in the Pitt-Rivers Museum. The energy of the curator, Mr. H. Balfour, who has paid three special visits to the Victoria Falls of the Zambezi, has resulted in the acquisition of a far more complete collection representing the archæology of that region than exists anywhere else. Other important accessions have come in from the Belgian Congo, British East Africa, West Africa, the Dordogne, and the Isle of Wight. In the department of experimental philosophy, Prof. Clifton reports that an extension of the laboratory is absolutely necessary, the only alternative being to restrict the number of students.

The report of the Wykeham professor of physics (Prof. Townsend) records the transference of the laboratory furniture and apparatus from the temporary quarters in the old museum to the fine new building provided by the senerosity of the Drapers' Company. The new premises have been found to be excellently adapted for giving practical instruction, and also for research work. In the department of chemistry, Prof. Odling notes the starting of a new course of advanced practical organic chemistry under Dr. Chattaway, and the publication of several important memoirs dealing with researches conducted in the chemical laboratory. These include Dr. Chattaway's work on chlorine, Mr. Marsh's on the solution of haloid double salts in organic solvents and on the halogen derivatives of camphor, and also the investigations by $\mathrm{Mr}$. Lambert and his pupils on the wet oxidation of metals. The report mentions that as a result of the work still in progress, it is hoped later to establish sufficient facts to warrant putting forward a modification of the present views on the subject of the corrosion of metallic iron.

A valuable consignment of rocks and fossils has been sent to the geological department from Peru, where $\mathrm{Mr}$. $\mathrm{J}$. A. Douglas is engaged in using the excellent opportunities for geological study now being afforded by several important railway cuttings. The expenses of the investigation are being borne by Mr, W. E. Balston, University College, and the consignment that has been already received is the first of many that may be expected as a result of Mr. Douglas's labours. Besides the usual field-work conducted by Prof. Sollas in the country about Oxford, an excursion, attended by sixteen students, was made to the Siebengebirge and the Eifel. Much work has been done by Miss Byrne and others on the rearrangement of the collections. A long series of specimens illustrating the history of the pleistocene epoch is in course of arrangement, and the work is rapidly approaching completion.

Like other heads of departments, the professor of rural economy (Prof. Somerville) finds himself somewhat embarrassed for want of room. The laboratories of botany and chemistry included in his department have been taxed to their utmost capacity to provide accommodation for the students. For the needs of the department of mineralogy, provision has been made by the allotment of a portion of the northern room of the old Radcliffe library, lately occupied by the Wykeham professor of physics. Many additions are recorded to the collections of specimens and the stock of apparatus, and some important researches have been carried on by Prof. Bowman, his pupils, and assistants.

A remarkable feature in many of the departmental reports that have now been briefly noticed, is the great and growing need of still further accommodation if the requirements of both teachers and students are to be satisfactorily met. Much has already been done; all departments alike tell the same tale of great and increasing activity in scientific work. Much still remains to do; but the document before us gives good hope for the future, for it contains abundant evidence that the ancient University of Oxford is becoming more and more alive to its responsibilities in the matter of scientific progress, as regards both teaching and research.

\section{ADVANCES IN REPTILIAN PALAONTOLOGY.}

IN the July number of The American Naturalist $\mathrm{Dr}$

O. P. Hay reopens the discussion with regard to the position of the limbs in Diplodocus and other sauropod dinosaurs, criticising the views of those who assert that these reptiles carried themselves in elephantine fashion, and maintaining his own opinion that the general pose was more after the crocodilian style. In regard to what may be called the elephant pose, it is pointed out that since a straight femur appears to have characterised the Proboscidea from the beginning, its occurrence in the modern representatives of the group may be regarded as a primitive feature, rather than an adaptation to the support of great bodily weight. At the conclusion of his arguments with regard to the pose of the sauropods, Mr. Hay expresses doubts as to whether the erect bird-like posture attributed to the carnivorous dinosaurs of the Jurassic is really true to nature. "The extraordinary development of the pubic bones of Aristosaurus, the expanded and anky. losed distal ends of which reached nearly half-way to the forelegs, seems to me to indicate that these animals, when in repose, had a prone position, resting much of the weight on the pubes, and that when running their legs straddled considerably.'

In reference to the opinion of Dr. Matthew that Sauropods were too bulky to have lived on land, it is added that "the law to which he gives expression does, of course, prescribe a limit to the size an animal can attain, but who has yet determined what that limit is?"

To vol. vii., part 4, of the Annals of the S. African พั. 2 I8O, VOL. 87] 